\title{
The resveratrol analogue, 3,4,5,4'-trans-tetramethoxystilbene, inhibits the growth of A375 melanoma cells through multiple anticancer modes of action
}

\author{
VASILIS P. ANDROUTSOPOULOS ${ }^{1,2}$, IRENE FRAGIADAKI ${ }^{1}$, \\ DEMETRIOS A. SPANDIDOS ${ }^{2}$ and ANDRONIKI TOSCA ${ }^{1}$ \\ ${ }^{1}$ Laboratory of Experimental Dermatology, and ${ }^{2}$ Laboratory of Clinical Virology, \\ University of Crete, Medical School, Heraklion 71003, Greece \\ Received May 25, 2016; Accepted July 13, 2016
}

DOI: $10.3892 /$ ijo.2016.3635

\begin{abstract}
Resveratrol is a natural dietary product that has demonstrated multifaceted anticancer activity. Several analogues of resveratrol have been synthesized in an effort to enhance the pharmacological potency and improve the pharmacokinetic properties of the compound. 3,4,5,4'-trans-tetramethoxystilbene $(3,4,5,4$ '-TMS) is a methoxylated analogue of resveratrol that has demonstrated anti-proliferative activity in vitro (in cancer cell lines) and in vivo (in xenograft models). In the present study, the anticancer effects of 3,4,5,4'-TMS in A375 human melanoma cells were examined. 3,4,5,4'-TMS markedly inhibited the proliferation of $\mathrm{A} 375$ cells $\left(\mathrm{IC}_{50}=0.7 \mu \mathrm{M}\right)$, via a mechanism involving mitotic arrest at the prometaphase stage of cell division. This effect was accompanied by the upregulation of the expression of the mitogen activated protein kinases, JNK and p38, and the concomitant activation of p38, that was verified by the nuclear translocation of the phoshorylated form of the protein. The pharmacological inhibition of $\mathrm{p} 38$ by SB203580 $(4 \mu \mathrm{M})$ attenuated the effects of 3,4,5,4'-TMS, as demonstrated by decreased cell cycle progression at the mitotic phase. Furthermore, 3,4,5,4'-TMS increased the total levels of Aurora A, while it inhibited the localization of the protein to the spindle poles. Finally, 3,4,5,4'-TMS exhibited anti-metastatic activity, inhibiting A375 cell migration and the attachment of the cells to a collagen type IV-coated surface. Collectively, the data suggest that 3,4,5,4'-TMS is an effective chemotherapeutic drug for the treatment of human melanoma and that it exerts its effects through multiple anticancer modes of action.
\end{abstract}

Correspondence to: Dr Vasilis P. Androutsopoulos, Laboratory of Clinical Virology, University of Crete, Medical School, Voutes, Heraklion 71003, Greece

E-mail: androuts@uoc.gr

Key words: resveratrol, tetramethoxystilbene, melanoma, p38, Aurora A

\section{Introduction}

Human melanoma is a malignant tumor that has increased in incidence over the past years worldwide. In the United States, it is estimated that 144,860 new cases of melanoma will be diagnosed in the year 2016 (1). During the period between 1975 and 2012, the incidence of melanoma has increased annually at a percentage of $3.2 \%$ in males and $2.4 \%$ in females (1). During the early stages of the disease, melanoma is curable through surgical excision (2). However, the majority of fatalities occur from secondary tumors originating from the metastatic spread of the cancer, as a result of ineffective chemotherapeutic treatment options, and eventually lead to a poor prognosis and the reduced survival of patients $(2,3)$. Of note, the annual costs for the treatment of melanoma in the United States have increased considerably from the year 2010 to 2015 (from approximately 400 to 650 million USD) and are expected to increase further in the years 2020 and 2030 (4). The therapeutic strategies that target human melanoma cells focus on multiple signaling pathways that are constitutively activated and play important roles in cell proliferation, cell survival and the resistance of the cancer cells to chemotherapeutic regimens. Phytochemical-related compounds have attracted considerable attention, due to their low cost, low toxicity and public acceptance as dietary chemopreventative agents (5).

Resveratrol (chemical strucure shown in Fig. 1A, bottom panel) is a naturally occurring phytoalexin found in grapes, cranberries and peanuts that is generated in response to pathogenic attack. Resveratrol has been shown to exert a wide diversity of biological effects, including the inhibition of the initiation, promotion and progression of cancer, the inhibition of cancer cell proliferation, the inhibition of kinase enzyme activity and the induction of apoptosis (6-9). Despite the multifaceted anticancer activity of resveratrol, the potency of this compound is hampered by the poor pharmacokinetic properties exhibited in vivo. 3,4,5,4'-trans-tetramethoxystilbene $(3,4,5,4$ '-TMS) (Fig. 1A, top panel) is a resveratrol analogue that contains methoxy group substitutions in place of the hydroxyl groups of the stilbene moiety. 3,4,5,4'-TMS has shown promising metabolic stability and bioavailability in a previous study conducted on C57BL/6 mice (10). In addition, 
3,4,5,4'-TMS has been shown to exert more potent inhibitory effects than resveratrol on the proliferation of cancer cells in vitro, whereas the anti-proliferative action of the compound is attributed to the induction of apoptosis and cell cycle arrest $(10,11)$.

A recent study conducted by our group demonstrated that $3,4,5,4^{\prime}$-TMS may effectively inhibit the proliferation of human melanoma cells by inducing apoptosis and cell cycle arrest, through the activation of the mitogen-activated protein kinase (MAPK), ERK1/2 (12). In the present study, the activation of the MAPK protein, p38, by 3,4,5,4'-TMS was investigated using A375 human melanoma cells. The induction of the expression of the mitosis-associated protein, Aurora A, was also examined. The data demonstrate that 3,4,5,4'-TMS possesses a pleiotropic spectrum of biological activities in human melanoma cells that includes the modulation of the cell cycle and cell signaling-associated proteins, the induction of apoptosis and the inhibition of metastasis.

\section{Materials and methods}

Materials and chemicals. 3,4,5,4'-TMS was purchased from Sigma-Aldrich (St. Louis, MO, USA). DMSO, ethanol, formaldehyde, paraformaldehyde, PBS, bovine serum albumin and propidium iodide were purchased from Sigma-Aldrich. SB203580 was purchased from Calbiochem (San Diego, CA, USA). Triton X-100 and 3-(4,5-dimethylthiazol-2-yl)-2,5-diphenyltetrazolium bromide (MTT) were purchased from Reasearch Organics Inc. (Cleveland, OH, USA) and RNAse was from Qiagen, Inc. (Valencia, CA, USA). Antibodies for JNK (Cat no. 9252), p38 (Cat no. 9211), p-p38 (Cat no. 9212) and Aurora A (Cat no. 3079) detection were from Cell Signaling Technology, Inc. (Beverly, MA, USA). Antibodies for $\beta$-tubulin (Cat no. sc-31782) and $\beta$-actin (Cat no. sc-47778) detection were purchased from Santa Cruz Biotechnology, Inc. (Dallas, TX, USA). Peroxidase conjugated secondary antibodies [goat anti-rabbit IgG (Cat no. 12-34) and rabbit anti-mouse $\operatorname{IgG}$ (Cat no. cat no. 06-371)] were purchased from Millipore (Temecula, CA, USA).

Cell culture. A375 cells that were used for the experiments were provided by the American Type Culture Collection (ATCC, Manassas, VA, USA) and were maintained in RPMI-1640 containing $10 \%(\mathrm{v} / \mathrm{v})$ heat-inactivated $\left(56^{\circ} \mathrm{C}\right.$ for $45 \mathrm{~min}$ to inactivate complement) fetal calf serum at $37^{\circ} \mathrm{C}$, $5 \% \mathrm{CO}_{2} / 95 \%$ air with $100 \%$ humidity and were passaged using trypsin-EDTA. The cultured cells were routinely passaged every 2-3 days. All cell culture reagents were purchased from Invitrogen Life Technologies (Carlsbad, CA, USA). Tissue culture flasks, multi-well plates and cell culture dishes were purchased from Corning Life Sciences (Tewksbury, MA, USA), and glass coverslips from Knittel-Gläser (Braunschweig, Germany).

MTT assay. A375 cells were plated in 96-well flat-bottomed plates, treated with $3,4,5,4^{\prime}$-TMS at a concentration range of $0.078-40 \mu \mathrm{M}$ and incubated for $96 \mathrm{~h}$ at $37^{\circ} \mathrm{C}$. The control cells were treated with DMSO $(0.1 \%$ v/v). Cell viability was determined spectrophotometrically using MTT as a substrate, as previously described (13).
Cell cycle analysis. A375 cells were incubated with 3,4,5,4'-TMS $(10 \mu \mathrm{M})$, SB203580 $(4 \mu \mathrm{M})$ or $0.1 \%$ DMSO (control cells) for 24,36 or $48 \mathrm{~h}$. The cells were washed twice with PBS, detached with trypsin-EDTA and centrifuged at 2,000 rpm for $5 \mathrm{~min}$. The cells were then washed twice with PBS and resuspended in $70 \%$ ethanol at $-20^{\circ} \mathrm{C}$ for $24 \mathrm{~h}$. The cells were then incubated with PI $(50 \mu \mathrm{g} / \mathrm{ml})$ containing RNase $(40 \mu \mathrm{g} / \mathrm{ml})$ for $30 \mathrm{~min}$ at $37^{\circ} \mathrm{C}$. The fluorescence intensity was determined using a Beckman Coulter flow cytometer (Beckman Coulter International SA, Nyon, Switzerland), using FL3 as the channel for fluorescence emission. At least 10,000 events were acquired and analysis was carried out using CXP multicomp cytometer analysis software (Beckman Coulter International SA).

Determination of mitotic index. A375 cells were seeded in $18 \times 18 \mathrm{~mm}$ coverslips at a density of $4 \times 10^{4}$ cells $/ \mathrm{ml}$, and incubated at $37^{\circ} \mathrm{C}$ for $24 \mathrm{~h}$ in the presence of $3,4,5,4^{\prime}-\mathrm{TMS}(10-30 \mu \mathrm{M})$. The cells were washed with PBS and fixed with $3.7 \%$ formaldehyde in PBS for $10 \mathrm{~min}$. Nuclear staining of the cells was carried out by incubation with $1 \mu \mathrm{M}$ TO-PRO-3 iodide (Molecular Probes; Invitrogen Life Technologies) for $10 \mathrm{~min}$. The cells were mounted using UltraCruz Mounting Medium with DAPI (Santa Cruz Biotechnology, Inc.) and analyzed using a confocal microscope (Leica Microsystems GmbH, Heidelberg, Germany). The mitotic index was determined according to the following formula: number of cells in mitosis/total number of cells x100. The experiment was carried out at least 3 times, and the results are expressed as the mean values \pm standard deviation (SD).

Confocal immunofluorescence. A375 cells were seeded in $18 \times 18 \mathrm{~mm}$ coverslips at a density of $5 \times 10^{4} \mathrm{cells} / \mathrm{ml}$, and incubated at $37^{\circ} \mathrm{C}$ for $24 \mathrm{~h}$ in the presence of $3,4,5,4^{\prime}-\mathrm{TMS}(10-30 \mu \mathrm{M})$. The cells were washed 3 times with PBS, fixed with $4 \%$ paraformaldehyde/PBS and permeabilized in $0.1 \%$ Triton X-100/PBS for 10 min. Following 3 washes with PBS, the cells were blocked with $1 \% \mathrm{BSA} / \mathrm{PBS}$ for $30 \mathrm{~min}$ and incubated with a primary antibody against $\beta$-tubulin and/or Aurora A (diluted 1:200 in $0.1 \% \mathrm{BSA} / \mathrm{PBS}$ ) overnight at $4^{\circ} \mathrm{C}$. The cells were then incubated with Alexa Fluor 555 goat anti-mouse IgG (Cat no. A-21422; Thermo Fisher Scientific, Waltham, MA, USA) secondary antibody in the case of $\beta$-tubulin, or with CF 488A goat anti-rabbit IgG secondary antibody (Cat no. 20012; Biotium, Inc., Hayward, CA, USA), in the case of p-p38 and for Aurora A (diluted 1:200 in $1 \% \mathrm{BSA} / \mathrm{PBS}$ ) for $1 \mathrm{~h}$. The cells were finally washed 3 times with PBS, stained with $1 \mu \mathrm{M}$ TO-PRO-3 iodide for $10 \mathrm{~min}$, and mounted with UltraCruz Mounting Medium with DAPI. Where appropriate, the cytoplasm was stained with rhodamine phalloidin (Invitrogen Life Technologies) for $40 \mathrm{~min}$ at room temperature (diluted 1:150 in in $0.2 \% \mathrm{BSA} / \mathrm{PBS}$ ), prior to incubation with the primary antibody.

Wound healing assay. A375 cells were seeded in 24-well plates at a density of $1 \times 10^{5}$ cells $/ \mathrm{ml}$ and incubated at $37^{\circ} \mathrm{C}$ for $24 \mathrm{~h}$ to reach $80-90 \%$ confluency. Wound healing was conducted by scratching the surface of each well with a sterile $10 \mu$ l pipette tip. The detached cells were removed by washing the cell layer twice with PBS. The wound closure was monitored in the presence of $5 \mu \mathrm{M} 3,4,5,4^{\prime}-\mathrm{TMS}$ at 12 or $24 \mathrm{~h}$, at different positions of the wound. The cellular motility was quantified using image 

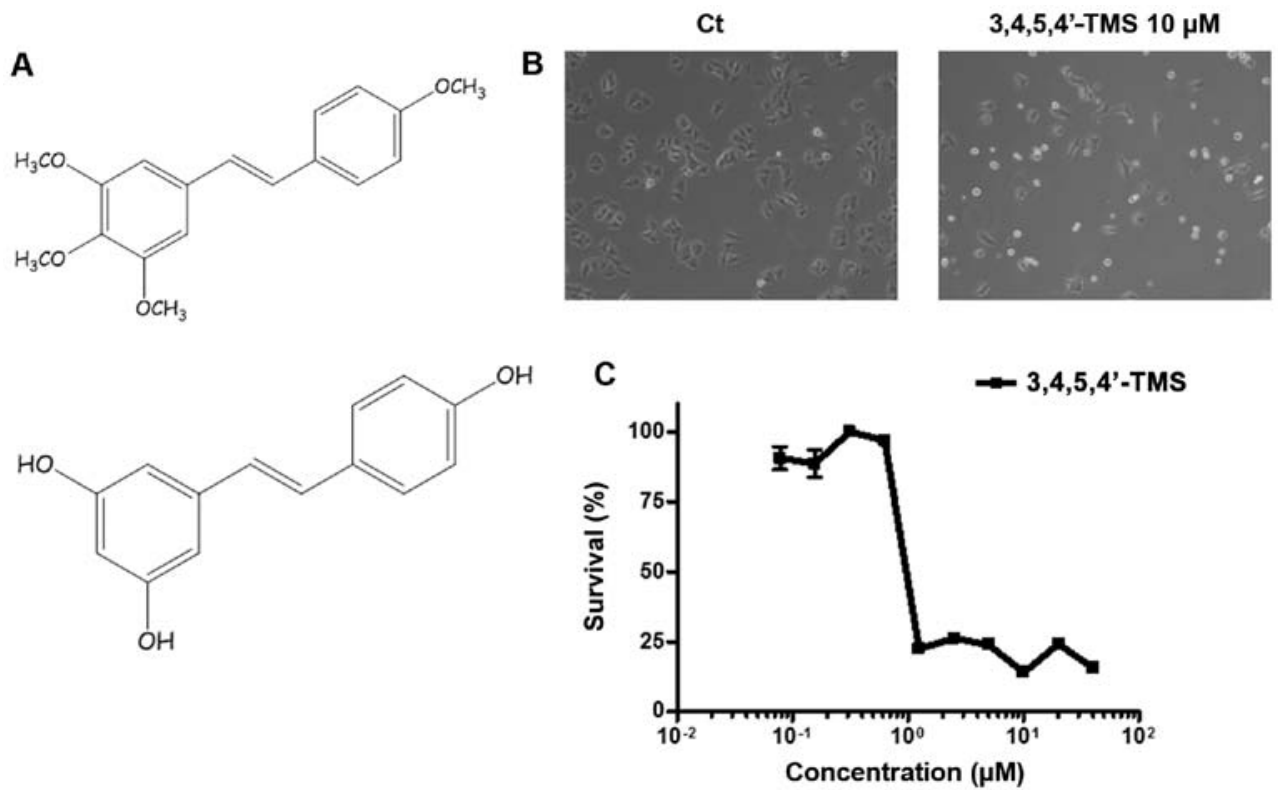

Figure 1. Anti-proliferative effect of the resveratrol analogue, 3,4,5,4'-trans-tetramethoxystilbene (3,4,5,4'-TMS), in A375 cells. (A) Chemical structures of 3,4,5,4'-TMS (upper panel) and resveratrol (bottom panel). (B) Light microscopy of A375 cells treated for $24 \mathrm{~h}$ with $10 \mu \mathrm{M}$ of 3,4,5,4' TMS. (C) MTT cell viability assay of A375 cells incubated with a concentration range of 3,4,5,4'-TMS $(0.078,0.156,0.3125,0,625,1.25,2.5,5,10,20$ and $40 \mu \mathrm{M})$ for $96 \mathrm{~h}$. The experiments were carried out at least 3 times and error bars indicate the means $\pm \mathrm{SD}$.

analysis (ImageJ 1.4.3.67 Launcher Symmetry Software). Wound healing assays were carried out in triplicate.

Attachment assay. The 24-well plates were coated overnight at $4^{\circ} \mathrm{C}$ with collagen type IV (50 $\mu \mathrm{g} / \mathrm{ml}$; Sigma-Aldrich) and were washed 3 times with PBS the following morning. The wells were blocked with $1 \%$ BSA for $2 \mathrm{~h}$ prior to the experiment. The cells were seeded in each well at a density of $4 \times 10^{5}$ cells $/ \mathrm{ml}$ in the presence or absence of $5 \mu \mathrm{M}$ of 3,4,5,4'-TMS and incubated at $37^{\circ} \mathrm{C}$ for the time periods of $45 \mathrm{~min}$, and 2 and $3 \mathrm{~h}$. The cells were washed 3 times with PBS and the cellular density was quantified by staining with trypan blue and counting using a haemocytometer. The attachment assays were conducted in triplicate.

Western blot analysis. A375 cells were plated out in T25 flasks at a density of $1.5 \times 10^{5}$ cells $/ \mathrm{ml}$ and incubated at $37^{\circ} \mathrm{C}$ for $24 \mathrm{~h}$ in the presence of 3,4,5,4'-TMS (20-50 $\mu \mathrm{M})$. The medium was removed and the cells were lysed with $100 \mu$ l of RIPA buffer (Sigma-Aldrich) containing protease inhibitor cocktail (Roche Diagnostics, Basel, Switzerland). The extraction of the protein was carried out by centrifugation at 13,000 rpm for $10 \mathrm{~min}$, at $4^{\circ} \mathrm{C}$. A total of $30 \mu \mathrm{g}$ of protein was loaded in $10 \%$ SDS-polyacrylamide mini gels and transferred by electroblotting onto PVDF membranes (Bio-Rad Laboratories, Inc., Hercules, CA). The membranes were blocked with $5 \%$ milk/0.1\% Tris-buffered saline with Tween-20 (TBS-T) at room temperature for $1 \mathrm{~h}$ by continuous shaking. The incubation with the primary antibodies (JNK, p38, p-p38, $\beta$-actin, Aurora A, diluted 1:500 or 1:200 in 1\% milk/0.1\% TBS-T) was carried out overnight at $4^{\circ} \mathrm{C}$. The membranes were washed 3 times with $0.1 \%$ TBS-T and incubated with secondary antibody (HRP; diluted 1:2,000 in 5\% milk/0.1\% TBS-T) at room temperature for $1 \mathrm{~h}$. The membrane-bound antibodies were visualized by the use of ECL western blotting detection reagent (Amersham Corp., Arlington Heights, IL, USA) on X-ray films (FujiFilm, Valhalla, NY, USA).

Statistical analysis. The data are presented as the average of at least 3 independent measurements and analyzed by a paired t-test and one-way ANOVA, using Microsoft Excel version 2007. P-values $<0.05$ were considered to indicate statistically significant differences.

\section{Results}

3,4,5,4'-TMS inhibits the growth of A375 melanoma cells at micromolar concentrations through a mechanism involving mitotic arrest at the prometaphase stage .3,4,5,4'-TMS has been shown to possess promising anti-proliferative activity in vitro in breast, ovarian and colon cancer cells $(10,11,14,15)$. Recently, we published a study that demonstrates the efficacy of 3,4,5,4'-TMS in human melanoma in vitro (12). In the present study, the results of the latter study were verified. The A375 cell line was selected in order to further examine the anti-proliferative and anticancer activity of 3,4,5,4'-TMS in human melanoma. An initial investigation of the A375 cells by phase contrast light microscopy revealed doublets of cells floating on the surface of the Petri-dish following $24 \mathrm{~h}$ of treatment with $10 \mu \mathrm{M}$ of 3,4,5,4'-TMS, compared with the control cells treated with the solvent alone (DMSO) (Fig. 1B). The incubation of the cells with 3,4,5,4'-TMS for longer periods of time (96 h), indicated that cellular growth was effectively inhibited at concentrations $<1 \mu \mathrm{M}\left(\mathrm{IC}_{50}=0.7 \mu \mathrm{M}\right)$, as demonstrated by MTT cell viability assay (Fig. 1C). Furthermore, FACS analysis was carried out following $24 \mathrm{~h}$ of treatment of the cells with $10 \mu \mathrm{M}$ of the drug, in order to provide additional insight into the mechanisms of action of 3,4,5,4'-TMS in human melanoma. Treatment with $3,4,5,4$ '-TMS arrested A375 cells at the G2/M phase of the cell cycle $(90 \pm 0.2 \%)$, with a simultaneous decrease in the number of 
A

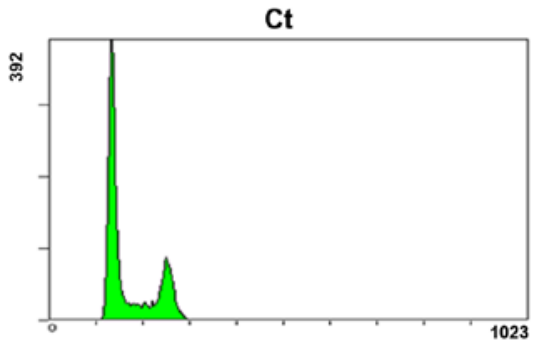

3,4,5,4-TMS $10 \mu \mathrm{M}$

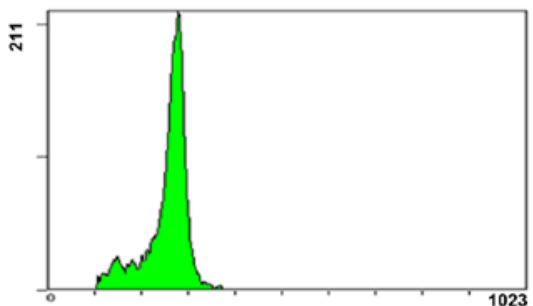

B

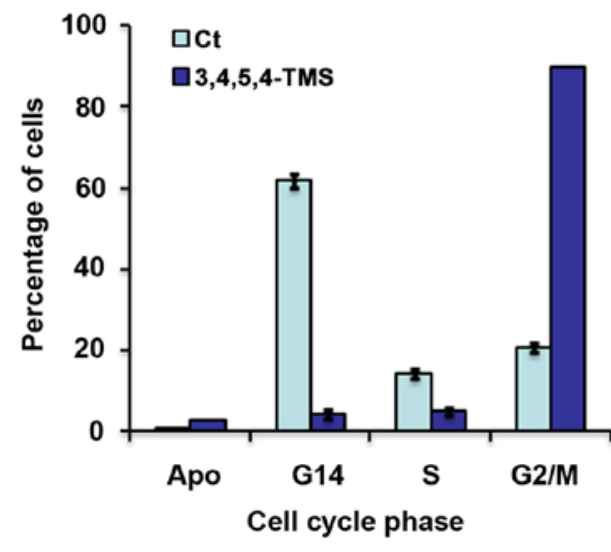

Figure 2. 3,4,5,4'-trans-tetramethoxystilbene (3,4,5,4'-TMS) causes cell cycle arrest of A375 cells at the G2/M phase. (A) Cell cycle analysis of A375 cells pretreated with 3,4,5,4' TMS $(10 \mu \mathrm{M})$ for $24 \mathrm{~h}$. (B) Percentages of cells in each phase of the cell cycle in the presence of the drug. Control cells were treated with $0.1 \%$ DMSO for $24 \mathrm{~h}$. Error bars indicate the means \pm SD from at least 3 independent determinations.

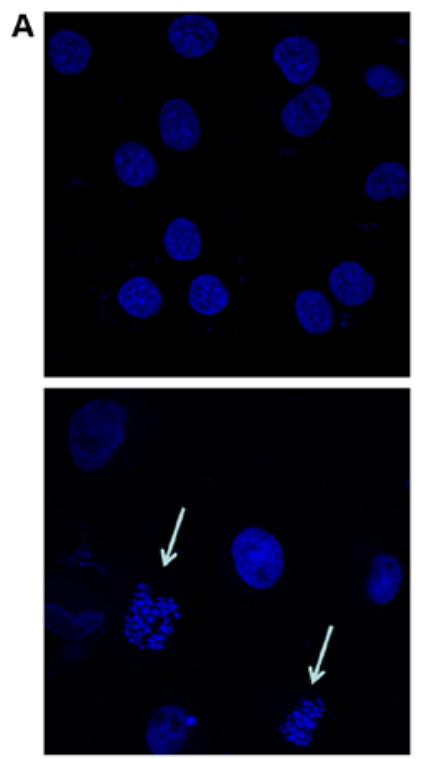

B

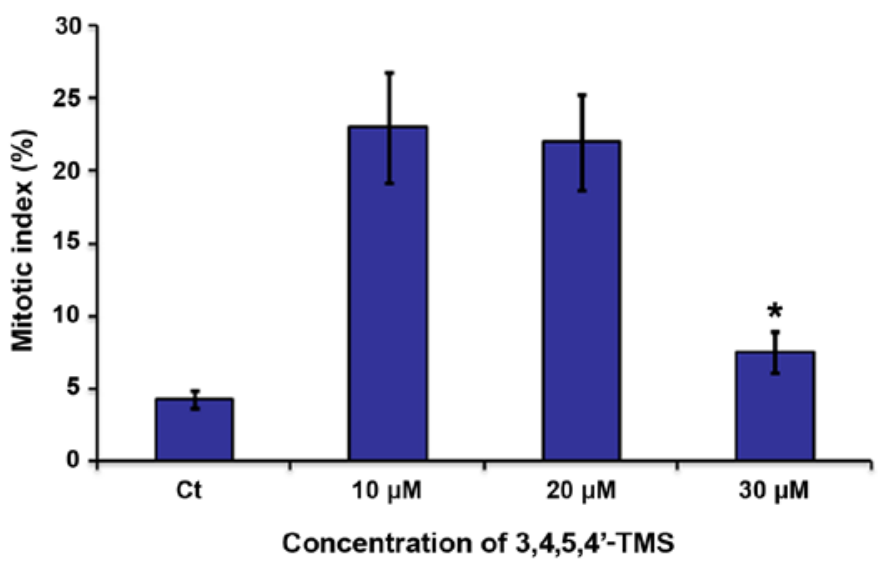

Figure 3. 3,4,5,4'-trans-tetramethoxystilbene (3,4,5,4'-TMS) induces mitotic arrest at the prometaphase in A375 cells. (A) Nuclear staining of A375 cells using TO-PRO-3 iodide in the presence/absence of 3,4,5,4-TMS $(10 \mu \mathrm{M})$ for $24 \mathrm{~h}$. White arrows indicate cells arrested at the prometaphase stage. (B) Percentage of cells undergoing mitosis in the presence of 3,4,5,4'-TMS (10-30 $\mu \mathrm{M})$. Control cells were treated with $0.1 \%$ DMSO for 24 h. Error bars indicate means \pm SD from at least 3 independent determinations. ${ }^{*} \mathrm{P}<0.05$, significant difference compared to the control.

cells in the G1 phase $(4.25 \pm 1 \%)$ and S phase $(4.75 \pm 1 \%)$, compared with the control cells (Fig. 2). In addition to G2/M arrest, $3,4,5,4^{\prime}$-TMS induced the apoptotic cascade of a small fraction of the A375 cell population ( $2.6 \pm 0.1$ vs. $0.7 \pm 0 \%$ for the control cells) (Fig. 2). Furthermore, experiments were carried out in order to determine whether the effects caused by 3,4,5,4'-TMS were attributed to $\mathrm{G} 2$ or $\mathrm{M}$ phase arrest. The cells were visualized by confocal microscopy following nuclear staining with TO-PRO-3. A large increase in the mitotic index (22-23 $\pm 4.8-5.3$ vs. $4.25 \pm 0.6 \%$ for control) was observed following incubation of A375 cells with 10 and/or $20 \mu \mathrm{M}$ of 3,4,5,4'-TMS for $24 \mathrm{~h}$ that was similar in ratio with the $\mathrm{G} 2 / \mathrm{M}$ blockage noted in the flow cytometry experiments (Fig. 3B). In parallel, visualization of the
A375 nuclei indicated the blockage of cell mitotic division at the prometaphase stage (Fig. 3A).

3,4,5,4'-TMS induces the activation of the cell signaling protein, p38, and requires active p38 for maximum potency. Based on the initial observation regarding the anti-mitotic activity of 3,4,5,4'-TMS, western blot analysis was carried out in order to examine the expression levels of key target proteins involved in cell signaling following incubation of A375 cells with the drug. The primary objective of the study was to examine whether MAPK signaling is important for the potency of 3,4,5,4'-TMS in A375 cells. Initially, an increase in the total levels of JNK was observed that was concentration-dependent. Furthermore, 
A

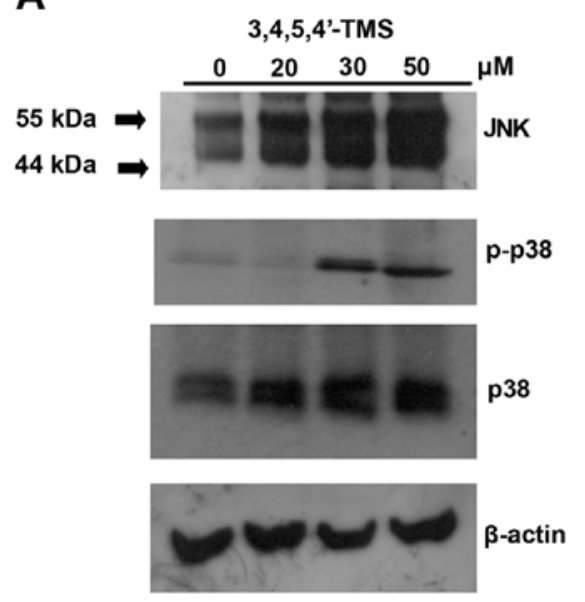

B

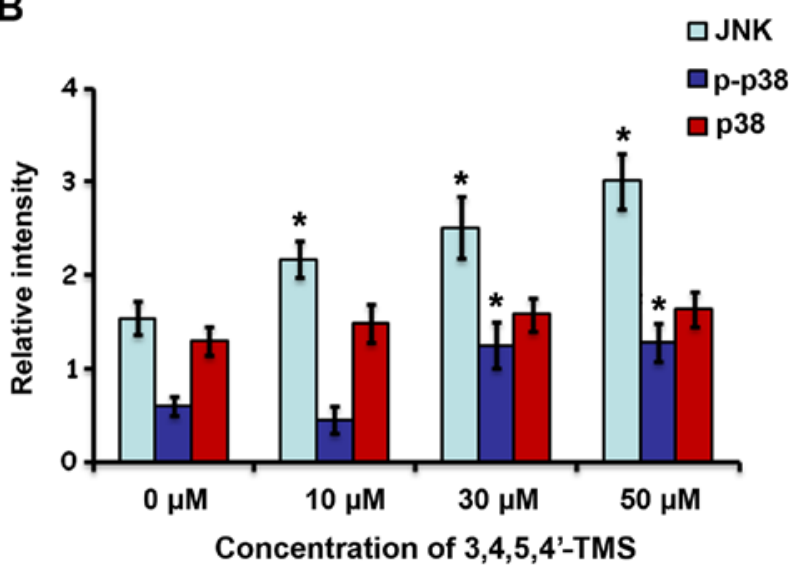

C
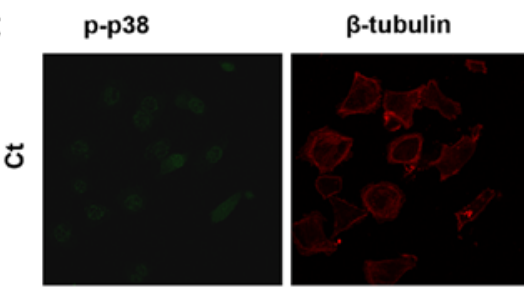

TO-PRO-3
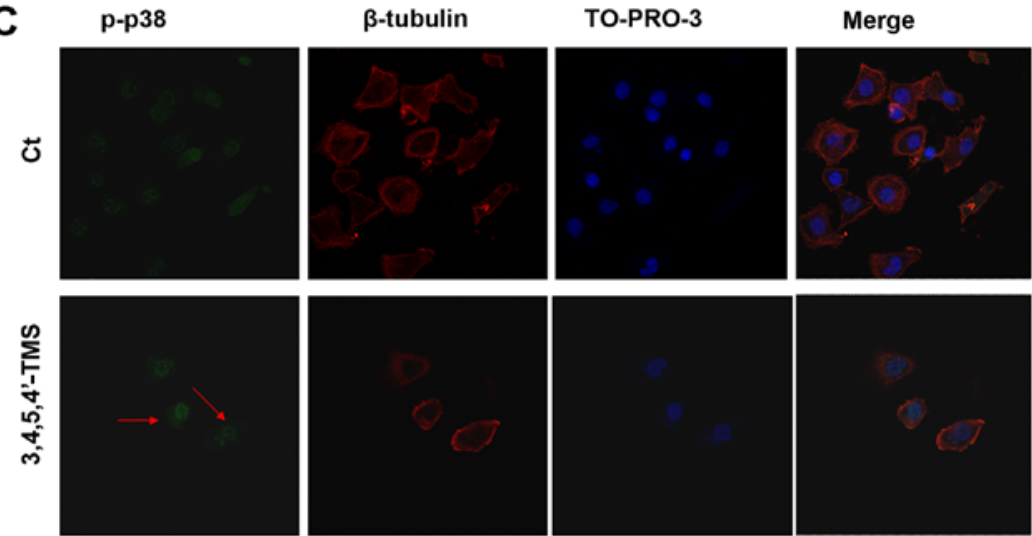

Figure 4. 3,4,5,4'-trans-tetramethoxystilbene (3,4,5,4'-TMS) induces the upregulation of the MAPK proteins, JNK and p38, in A375 cells. (A) Western blot analysis of cell cycle protein markers in cells pre-treated with 20,30 and $50 \mu \mathrm{M}$ of 3,4,5,4'-TMS for $24 \mathrm{~h}$. (B) Computer densitometry indicating relative expression of the proteins in A375 cells following treatment with 3,4,5,4'-TMS. (C) Confocal microscopy indicating nuclear translocation of p-p38 in A375 cells pre-treated with $30 \mu \mathrm{M}$ of 3,4,5,4'-TMS. Red arrows indicate more intense green staining in the nuclear region. Blue, TO-PRO-3 iodide staining; red, CF 488A staining; green, Alexa Fluor 555 staining. " $\mathrm{P}<0.05$, significant difference compared to the control.

the levels of the phosphorylated form of p38 were significantly increased following treatment of the cells with 30 and $50 \mu \mathrm{M}$ of 3,4,5,4'-TMS (Fig. 4A and B). The protein expression levels of p38 exhibited a similar increasing pattern (Fig. 4A and B). Additional experiments using confocal microscopy were conducted, in order to confirm that $\mathrm{p} 38$ is activated based on the localization of the phosphorylated form of the protein in the cell. p-p38 was translocated to the nucleus of the A375 cells following treatment with 3,4,5,4'-TMS, as demonstrated by intense staining of the protein in the nuclear regions of the cells. In contrast to these findings, the cells that were treated with DMSO alone exhibited weaker staining of p-p38 that was localized across the nuclear and cytoplasmic regions (Fig. 4C).

Given that $\mathrm{p} 38$ is activated in response to treatment with 3,4,5,4'-TMS, the present investigation was expanded, in order to determine whether the inhibition of p38 activity is essential for the potency of the drug. A375 cells were incubated with the p38 inhibitor (p38i), SB203580, at $4 \mu \mathrm{M}$ in the presence or absence of 3,4,5,4'-TMS. The pharmacological inhibition of p38 caused the arrest of A375 cells at the G1 phase along with G2/M phase arrest caused by 3,4,5,4'-TMS (Fig. 5A). The p38i, SB203580, attenuated the potent effects of 3,4,5,4'-TMS and concomitant treatment with SB203580 and 3,4,5,4'-TMS decreased the percentage of cells arrested in the $\mathrm{G} 2 / \mathrm{M}$ phase to $51.5 \pm 4.7 \%$ as opposed to $82 \pm 5.2 \%$ in the case of treatment with 3,4,5,4'-TMS alone (Fig. 5B). The incubation of A375 cells with SB203580 $(4 \mu \mathrm{M})$ and $20 \mu \mathrm{M}$ of 3,4,5,4'-TMS for longer periods of time $(36 \mathrm{~h})$, resulted in a lower number of cells undergoing G1 phase arrest, compared with the treatment of the cells with $10 \mu \mathrm{M}$ of the drug for $24 \mathrm{~h}$ (Fig. 5A). In contrast to these observations, the inhibition of p38 did not reduce the percentage of A375 cells undergoing late apoptosis in the presence of $3,4,5,4^{\prime}-\mathrm{TMS}$ for $24 \mathrm{~h}(3.2 \pm 0.2$ vs. $3.5 \pm 0.3 \%)$, as demonstrated by FACS analysis (Fig. 5A and B).

\section{3,4,5,4'-TMS induces the upregulation of Aurora A and causes} a localization shift from the spindle poles. The expression of the mitosis-associated protein, Aurora A, was examined in order to provide insight into the mechanisms responsible for the anti-mitotic action of 3,4,5,4'-TMS. Aurora A was detected at the prometaphase stage of A375 mitotic cell division and the protein was localized to both spindle poles (Fig. 6A). In the presence of $3,4,5,4$ '-TMS, Aurora A was localized to the middle of the cell, while the mitotic spindle poles were absent. The staining of $\beta$-tubulin in the cytoplasm was very weak, indicating mitotic catastrophe caused by the drug (Fig. 6A). When 
A

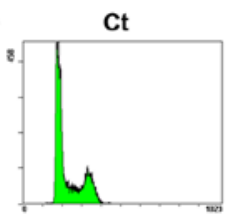

3,4,5,4'-TMS 24 h $10 \mu \mathrm{M}$

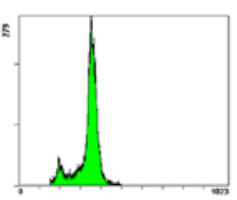

$3,4,5,4^{\prime}-$ TMS 36 h $20 \mu \mathrm{M}$

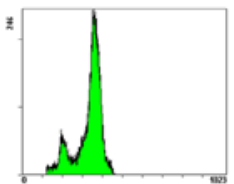

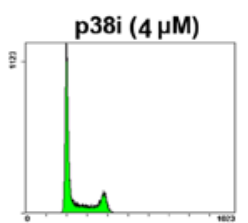

$3,4,5,4^{\prime}-T_{M S}(10)+p 38$

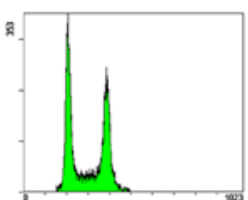

$3,4,5,4$ '-TMS $(20)+p 38 i 36 \mathrm{~h}$

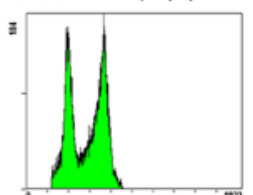

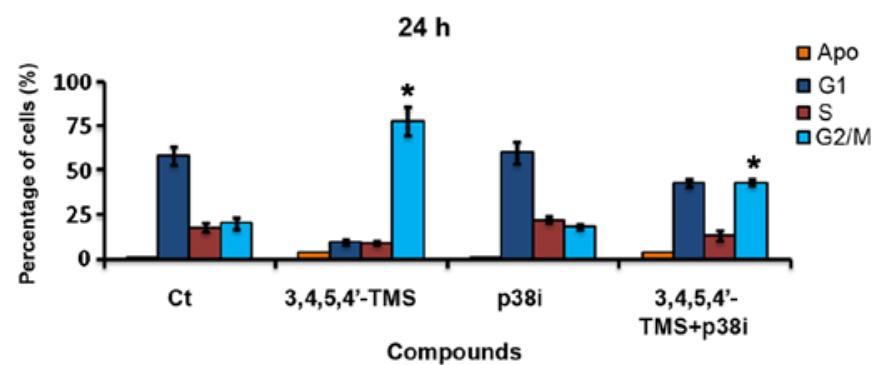

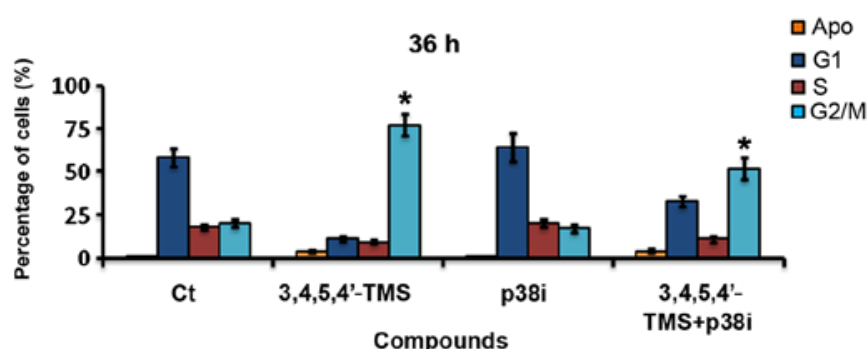

Figure 5. Pharmacological inhibition of p38 attenuates 3,4,5,4'-trans-tetramethoxystilbene (3,4,5,4'-TMS)-mediated cell cycle arrest of A375 cells. (A) Cell cycle histograms of A375 cells treated with: i) $0.1 \%$ DMSO for $24 \mathrm{~h}$; ii) $4 \mu \mathrm{M}$ of the p38i SB203580 for $24 \mathrm{~h}$; iii) $10 \mu \mathrm{M}$ of 3,4,5,4' TMS alone for $24 \mathrm{~h}$; iv) SB203580 $(4 \mu \mathrm{M})$ and 3,4,5,4' TMS $(10 \mu \mathrm{M})$ for $24 \mathrm{~h}$; v) $20 \mu \mathrm{M}$ of 3,4,5,4' TMS alone for $36 \mathrm{~h}$; and vi) SB203580 $(4 \mu \mathrm{M})$ and 3,4,5,4' TMS (20 $\mu \mathrm{M})$ for $36 \mathrm{~h}$. (B) Percentages of cells pre-treated with DMSO $(0.1 \%), 3,4,5,4^{\prime}$ TMS $(10$ or $20 \mu \mathrm{M})$, p38i $(4 \mu \mathrm{M})$ or p38i $(4 \mu \mathrm{M})+3,4,5,4^{\prime}-\mathrm{TMS}(10$ or $20 \mu \mathrm{M})$ for 24 or $36 \mathrm{~h}$ in each phase of the cell cycle. Apoptosis was quantified by the percentage of cells at the subG1 peak of the histogram. Experiments were carried out in triplicate. $* \mathrm{P}<0.05$, significant difference compared to the 3,4,5,4' TMS-treated group.

A
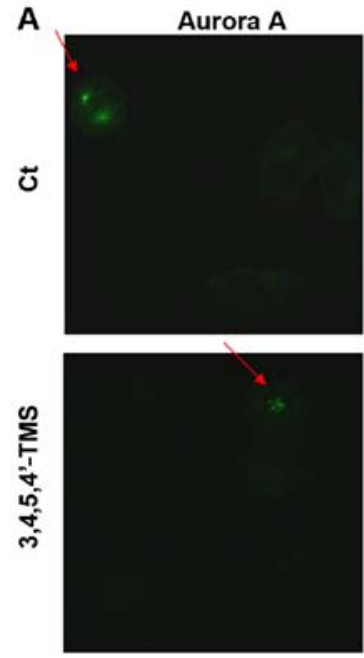

B
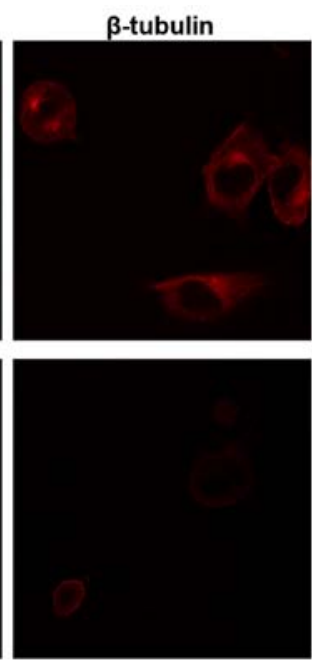

C

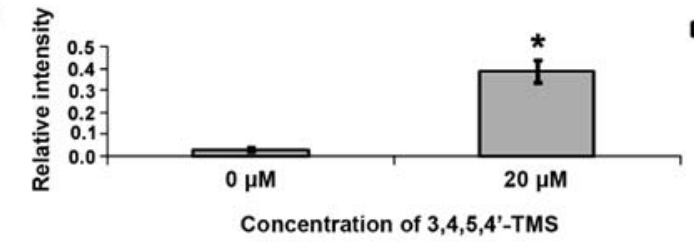

Merge
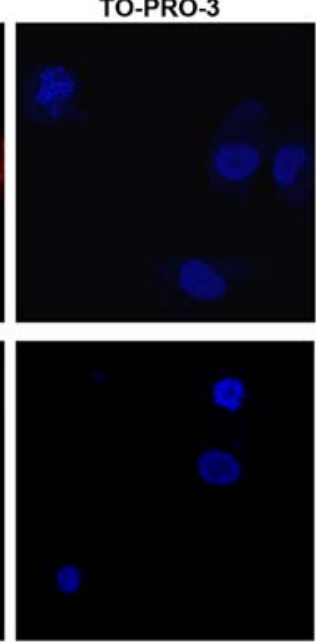
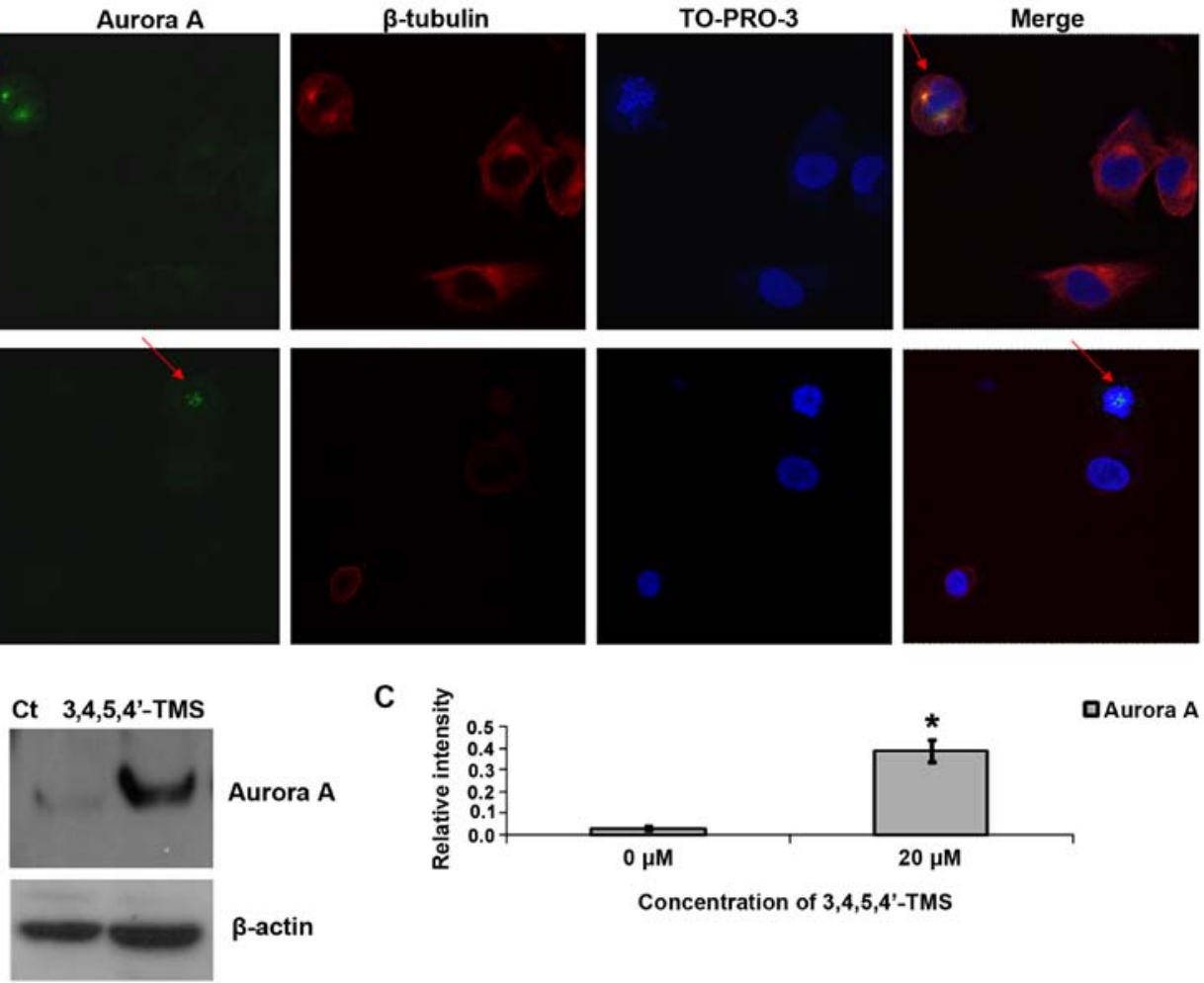

Aurora A

$\beta$-actin

Figure 6. 3,4,5,4'-trans-tetramethoxystilbene (3,4,5,4'-TMS) induces the upregulation of Aurora A and the dissociation of the protein from the spindle poles. (A) Confocal immunofluorescence of A375 cells pre-treated with $10 \mu \mathrm{M}$ of 3,4,5,4'-TMS for $12 \mathrm{~h}$. Blue, TO-PRO-3 iodide staining; red, CF 488A staining; green, Alexa Fluor 555 staining. Red arrows indicate the localization of Aurora A in the pressure and/or absence of 3,4,5,4'-TMS. (B) Representative blots indicating Aurora A protein expression levels following treatment with 3,4,5,4' TMS (10 $\mu \mathrm{M})$ for $24 \mathrm{~h}$. (C) Relative intensity of Aurora A expression. Experiments were carried out in triplicate. ${ }^{*} \mathrm{P}<0.05$, significant difference compared to the control.

the expression was monitored by western blot analysis, a clear upregulation of the protein was noted following treatment with
3,4,5,4'-TMS when compared with the control cells treated with DMSO (Fig. 6B and C). 
A

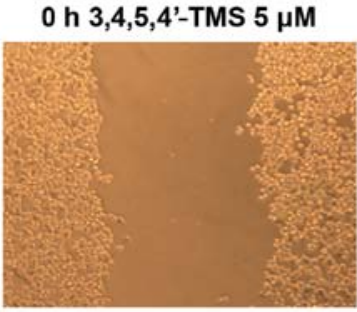

12 h $3,4,5,4^{\prime}-$ TMS $5 \mu M$
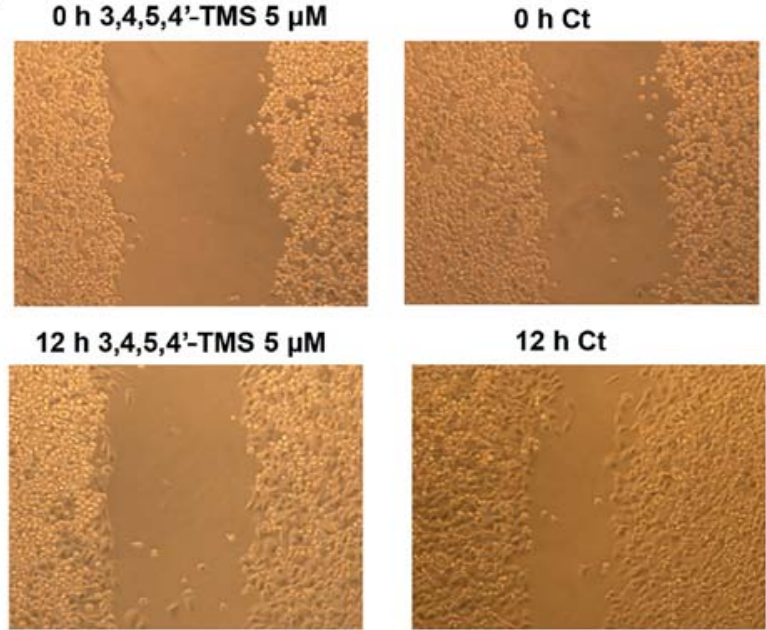

$12 \mathrm{~h} \mathrm{Ct}$

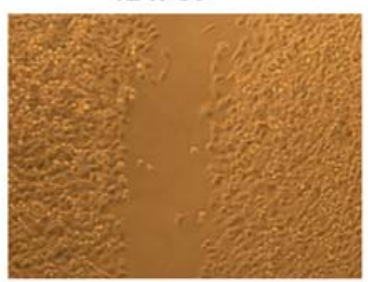

B

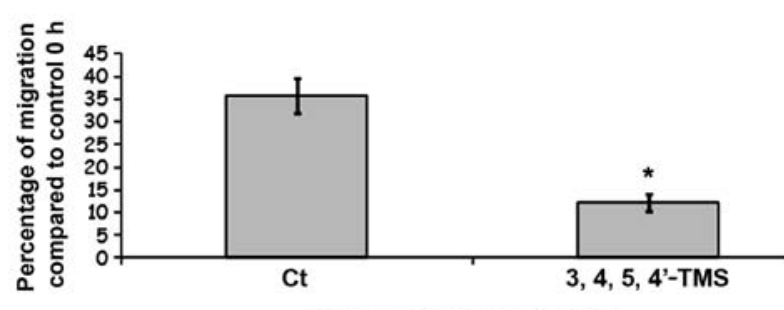

A375 cell treatment ( $12 \mathrm{~h})$

C

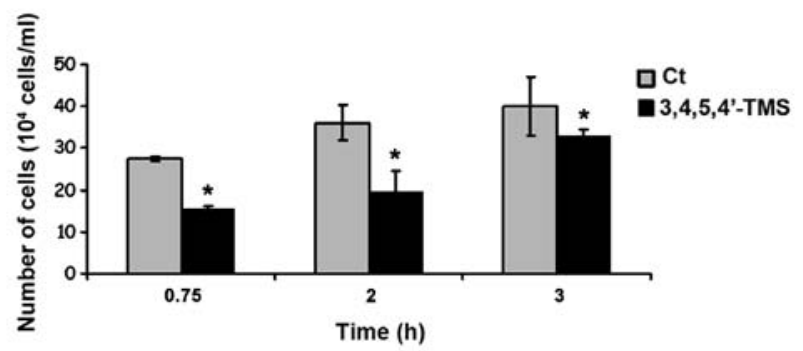

Figure 7. 3,4,5,4'-trans-tetramethoxystilbene (3,4,5,4'-TMS) inhibits the migration and attachment of A375 cells. (A) Wound healing assay of A375 cells that were treated with 3,4,5,4'-TMS $(5 \mu \mathrm{M})$ for $12 \mathrm{~h}$. (B) Percentage of inhibition of cell migration mediated by $3,4,5,4$ '-TMS, compared to control cells containing DMSO. (C) Inhibition of A375 cellular attachment to collagen type IV-coated surface by $5 \mu \mathrm{M}$ of $3,4,5,4^{4}-\mathrm{TMS}$ at $45 \mathrm{~min}, 2$ and $3 \mathrm{~h}$. ${ }^{*} \mathrm{P}<0.05$, significantly different than control. Images are traces of 1 out of 3 independent determinations.

3,4,5,4'-TMS exhibits anti-metastatic activity in A375 cells. Having established that 3,4,5,4'-TMS effectively inhibits the growth and proliferation of A375 cells, the effects of the drug on melanoma cell migration and attachment were further examined. For this purpose, wound healing and cell attachment assays were employed. The compound 3,4,5,4'-TMS $(5 \mu \mathrm{M})$ reduced the wound-healing ability of A375 cells following $12 \mathrm{~h}$ of treatment compared to the control samples (Fig. 7A). Similar results were obtained for $24 \mathrm{~h}$ of treatment (data not shown). Specifically, 3,4,5,4'-TMS reduced the migration of the cells at $12 \mathrm{~h}$ to $12 \pm 2 \%$, compared with $36 \pm 4 \%$ corresponding to the control samples (Fig. 7B). In addition 3,4,5,4'-TMS significantly inhibited the attachment of the cells on collagen type IV-coated 6-well plates at $45 \mathrm{~min}$, and at the 2 - and 3-h time points (Fig. 7C). The effect was more profound at earlier time points when compared with the control cells treated with DMSO alone (Fig. 7C).

\section{Discussion}

Natural products have played a pivotal role in the identification of new treatment strategies for cancer. The enhancement of the potency and efficacy of natural products by utilizing synthetic strategies is an attractive avenue for the design of effective anticancer drugs. 3,4,5,4'-TMS is a small molecular weight anticancer drug that possesses enhanced potency and bioavailability compared with the parent molecule, resveratrol. The current study presents a comprehensive report of 3,4,5,4'-TMS activity in A375 human melanoma cells. In addition to the inhibition of cell proliferation, 3,4,5,4'-TMS impeded the migration of A375 cells, thus presenting an effective therapeutic strategy for the treatment of human metastatic melanoma. The mechanism of action of 3,4,5,4'-TMS involves mitotic arrest, the induction of apoptosis and the activation of the p38 and Aurora A proteins. The molecular events associated with the anticancer effects of 3,4,5,4'-TMS in human melanoma cells are summarized in Fig. 8.

$3,4,5,4$ '-TMS has been examined in vitro in terms of cytotoxicity in breast, liver, ovarian, colon cancer and melanoma cell lines. The cytotoxicity of $3,4,5,4^{\prime}$-TMS is estimated at submicromolar concentrations, in terms of $\mathrm{IC}_{50}$ values, for breast liver and ovarian cancer cells (0.3-0.7 $\mu \mathrm{M}$ for MCF7 breast, HepG2 liver and A2780 ovarian cancer cells), whereas in colon cancer cells, the compound appears less potent $(11.5 \mu \mathrm{M}$ for HT-29 colon cancer cells) $(10,11,15)$. In human melanoma cells, 3,4,5,4'-TMS exhibited an $\mathrm{IC}_{50}$ value in the range of $0.5-1.25 \mu \mathrm{M}$ (Bro and A375 cells, $0.5 \mu \mathrm{M}$; MeWo and M5 melanoma cells, $1.25 \mu \mathrm{M}$ ) (12). It is evident from these studies that some cell lines appear to be more sensitive to $3,4,5,4^{\prime}$-TMS anti-proliferative activity compared to others. In the present study 3,4,5,4'-TMS exhibited submicromolar toxicity in A375 cells, which indicates that the latter cell line shows selectivity towards the drug, as in the case of Bro, HepG2, A2780 and MCF7 cells.

Mechanistically, in this study, 3,4,5,4'-TMS was shown to inhibit the cell cycle of A375 cells by inhibiting mitotic cell division at the prometaphase stage, as a result of the disassembly of the mitotic spindle. In contrast to the studies of Ma et al (11) and Piotrowska et al (15), in this study, the A375 human melanoma cell line was shown to be somewhat resistant to the apoptosis induced by 3,4,5,4'-TMS (approximately 5\% of the cells underwent apoptosis), compared with the MCF7, HepG2 and A2780 cells in previous studies, where a greater percentage of cells was shown to undergo apoptosis $(10-20 \%)(11,14,15)$. Methoxylated stilbenes containing $\geq 3$ methoxy substitutions induce the apoptotic cascade and the mitotic catastrophe of cancer cells $(16,17)$. The potency of each drug is dependent on the cis or trans configuration. The stilbenes bearing a cis configuration possess greater potency than the corresponding stilbenes bearing a trans configuration $(16,18)$. The mitotic catastrophe that is induced by methoxylated stilbenes precedes the induction of apoptosis, which is a secondary phenomenon that occurs due to the perturbed cellular division. With regard to the activity of 3,4,5,4'-TMS in A375 cells, there are two possible explanations for the diminished capacity of the drug to induce 


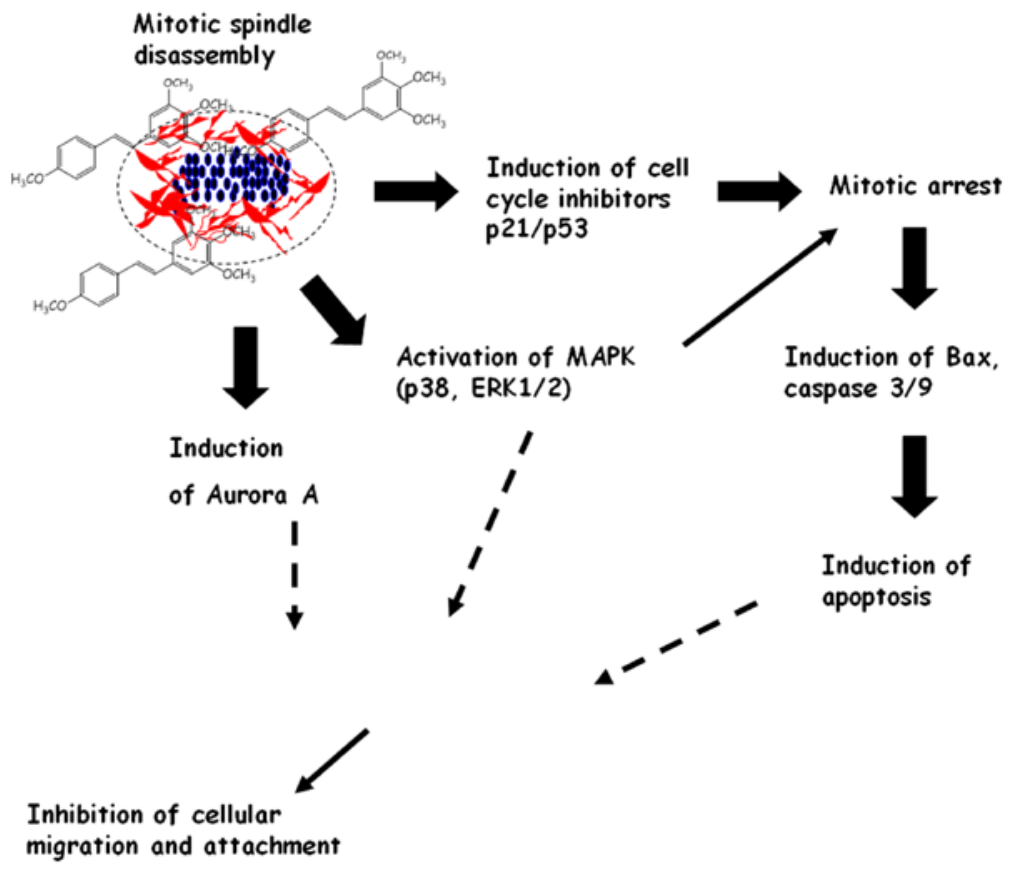

Figure 8. Schematic diagram depicting the molecular mechanism of anticancer action of 3,4,5,4'-trans-tetramethoxystilbene in human melanoma cells. In addition to the current study, the compound has been shown to activate ERK1/2, enhance the levels of the cell cycle inhibitors p21 and p53 and induce apoptosis via the modulation of the proteins, caspase-3, caspase-9 and Bax in A375 cells (12).

apoptosis: i) 3,4,5,4'-TMS is a trans analogue, thus it is not as potent as cis methoxy stilbenes, such as combretastatin A4 (CA4) in inducing mitotic arrest and consequently apoptosis; and ii) A375 and melanoma cells in general, are resistant to the induction of apoptosis when exposed to chemotherapeutic agents via the activation of different protective mechanisms (19). Furthermore, human melanoma cells show decreased apoptosis at the sites of tumor lesions that may explain their high metastatic potential (20). In concordance with the results presented in the present study, a recent study demonstrated that a structurally similar stilbene to 3,4,5,4'-TMS, bearing the cis orientation (cis-3,4',5-trimethoxy-3'-aminostilbene), was capable of inducing apoptosis in HCT116 colon cancer cells, but not in B16/F10 melanoma cells (21).

In an effort to identify plausible targets of 3,4,5,4'-TMS in A375 cells, the study focused on the MAPKs, p38 and JNK. Initial experiments revealed that 3,4,5,4'-TMS induced the phosphorylation of $\mathrm{p} 38$ and the upregulation of JNK proteins. Furthermore, the p38 pathway was shown to be essential for the potency of 3,4,5,4'-TMS, as the pharmacological inhibition of p38 led to a decrease in the percentage of human melanoma cells arrested in the G2/M phase. The p38 MAPKs are a class of protein kinases that have been characterized to respond to stress stimuli, such as UV radiation, cytokines and osmotic shock. Previous studies have highlighted the interplay of p38 with the intracellular events triggered by microtubule-interfering agents $(22,23)$. It has been shown that CA4, a highly potent methoxylated stilbene bearing the cis orientation, is capable of stimulating the activation of both p38 and ERK kinases in the BEL-7402 hepatocellular carcinoma cell line (24). The p38 kinase is involved in the reassembly of microtubules following exposure to CA4. However, in contrast to the present study where the inhibition of $\mathrm{p} 38$ attenuated the cell cycle arrest of human melanoma cells caused by 3,4,5,4'-TMS, the inhibi- tion of p38 in hepatocellular carcinoma cells was reported to enhance CA4 cytotoxicity (24). The reason for this apparent contradiction possibly lies on the structural dissimilarity of the compounds 3,4,5,4'-TMS and CA4, that determines the precise mechanism of the antimitotic action. 3,4,5,4'-TMS has been shown to enhance tubulin polymerization and is predicted to bind to tubulin at the paclitaxel binding site, whereas CA4 inhibits tubulin polymerization and binds to tubulin at the colchicine binding site $(11,24)$. Despite this discrepancy, the data presented in the current study are in alignment with previous studies that have identified the p38 pathway as a crucial signaling network that determines the activity of antimitotic drugs.

In this study, in addition to $\mathrm{p} 38$ activation, 3,4,5,4'-TMS was shown to induce the upregulation of Aurora A expression. The finding that the total levels of Aurora A protein are increased following treatment with certain antimitotic drugs has been demonstrated in a recent study in the cases of the microtubule stabilizers, taccalonolide and laulimalide (25). Aurora A and related microtubule-associated proteins have been reported to be activated in response to treatment with antimitotic drugs (25). 3,4,5,4'-TMS exhibited a similar pattern of Aurora A upregulation. However, although the protein levels were increased following treatment with 3,4,5,4'-TMS, Aurora A did not follow the same localization pattern as in the control cells, while the intensity of the protein expression was weak, as demonstrated by immunofluoresence experiments. This occurred due to the extensive mitotic spindle damage caused by $3,4,5,4^{\prime}-\mathrm{TMS}$. The protein Aurora A associates with the mitotic poles and adjacent spindle microtubules during mitosis and is critical for the proper formation of the mitotic spindle via the recruitment of several microtubule-associated proteins. As 3,4,5,4'-TMS causes the enhancement of tubulin polymerization and as a result, unstable microtubules and spindle formation, Aurora A was not detected at the spindle poles during the pro-metaphase and/or metaphase 
stages. The increase in the total levels of the protein is consistent with the incidence of the delayed progression of the cells through mitosis. The expression of Aurora A was increased in the 3,4,5,4'-TMS-treated A375 cells, possibly as a mechanism to overcome the mitotic arrest caused by the compound at the prometaphase stage of cell division.

In addition to the aforementioned findings, the present study demonstrated the ability of 3,4,5,4'-TMS to inhibit migration and attachment of A375 human melanoma cells on collagen type IV-coated plates. This, to the best of ourknowledge, provides the first preliminary evidence of the anti-metastatic activity of 3,4,5,4'-TMS. Human melanoma is a highly metastatic malignancy and a high percentage of melanoma-associated deaths occur as a result of secondary metastases of the tumors (26). Molecules resembling 3,4,5,4' TMS structure have been characterized as antimetastatic, although the mechanisms underlying their action remain somewhat enigmatic. One example includes the compound CA4 that has entered clinical phase II/III trials for the treatment of several malignancies $(27,28)$. A second molecule with anti-angiogenic and vascular-disrupting properties is stilbene 5c, a cis tri-methoxylated aminostilbene with similar potency to that of CA4 (21). In addition, two recent studies have documented that the compounds, 4-4'-dihydroxy-trans stilbene and 3,5,4'-trimethoxy trans stilbene (the methoxylated analogue of resveratrol), exert anti-invasive effects via the downregulation of MMP-9 and MMP-2 activities, as well as the modulation of the adhesion molecule, E-cadherin $(29,30)$. It is possible that $3,4,5,4$ '-TMS modulates the activities of the aforementioned proteins, although further research is required to establish such a hypothesis. To our knowledge, only one study has addressed the anti-invasive effects of 3,4,5,4'-TMS or DMU-212 on VEGF-stimulated HUVEC migration (30). $3,4,5,4$ '-TMS has been reported to be effective at concentrations between 5 and $80 \mu \mathrm{M}$ at the 24- and 48-h time points (31), which is in agreement with the data presented in this study.

Recent studies conducted in the field of cancer research and experimental therapeutics have highlighted the importance of the MAPK signaling pathways in the development of novel chemotherapeutic drugs for the treatment of cutaneous and/or metastatic melanoma $(2,32)$. An example includes the compound, vemurafenib, that is currently undergoing clinical phase II/III evaluation for the treatment of advanced and/or metastatic melanoma (32). Vemurafenib inhibits the kinase domain of the B-RAFV600E mutant protein and results in the inhibition of MEK and ERK phosphorylation (32). In addition to these promising findings, MAPK inhibitors are tested in combination therapy in patients that have developed resistance to standard melanoma therapy (32). In the present study, 3,4,5,4'-TMS demonstrated an antagonistic action with the p38i, SB203580, in A375 cells and additional research is required to fully elucidate the exact mechanism of action of this compound. Nevertheless, the results of our current and previous studies (12), conducted on 3,4,5,4'-TMS and human melanoma, have indicated that the compound targets the p38 and the ERK1/2 pathways, and thus a potential interaction between mitosis inhibition and MAPK signaling is expected. Future studies are required to focus on the interaction of 3,4,5,4'-TMS with B-RAF inhibitors in human melanoma.

In conclusion, the current study examined the anticancer activity of 3,4,5,4'-TMS in A375 human melanoma cells. The data indicate that $3,4,5,4^{\prime}-\mathrm{TMS}$ effectively inhibits the proliferation of melanoma cells through a mechanism involving mitotic arrest at the prometaphase stage of cell division, via the disassembly of the mitotic spindle and the induction of apoptosis. Importantly, the activation of the $\mathrm{p} 38$ and Aurora A proteins is required for the growth-inhibiting action of 3,4,5,4'-TMS, while the latter compound exhibits anti-invasive and anti-metastatic properties. Taken together, the results suggest that 3,4,5,4'-TMS is an effective therapeutic drug for use in the treatment of human melanoma that warrants further investigation in vivo.

\section{Acknowledgements}

This study was funded by the Hellenic non-profitable company of Dermatological Research.

\section{References}

1. Tripp MK, Watson M, Balk SJ, Swetter SM and Gershenwald JE: State of the science on prevention and screening to reduce melanoma incidence and mortality: The time is now. CA Cancer J Clin: May 27, 2016 (Epub ahead of print).

2. Russo AE, Torrisi E, Bevelacqua Y, Perrotta R, Libra M, McCubrey JA, Spandidos DA, Stivala F and Malaponte G: Melanoma: Molecular pathogenesis and emerging target therapies (Review). Int J Oncol 34: 1481-1489, 2009.

3. Wong CY, Helm MA, Kalb RE, Helm TN and Zeitouni NC: The presentation, pathology, and current management strategies of cutaneous metastasis. N Am J Med Sci 5: 499-504, 2013.

4. Guy GP Jr, Thomas CC, Thompson T, Watson M, Massetti GM and Richardson LC; Centers for Disease Control and Prevention (CDC): Vital signs: Melanoma incidence and mortality trends and projections - United States, 1982-2030. MMWR Morb Mortal Wkly Rep 64: 591-596, 2015.

5. Pal HC, Hunt KM, Diamond A, Elmets CA and Afaq F: Phytochemicals for the management of melanoma. Mini Rev Med Chem: Feb 11, 2016 (Epub ahead of print).

6. Sale S, Tunstall RG, Ruparelia KC, Potter GA, Steward WP and Gescher AJ: Comparison of the effects of the chemopreventive agent resveratrol and its synthetic analog trans 3,4,5,4'-tetramethoxystilbene (DMU-212) on adenoma development in the Apc(Min+) mouse and cyclooxygenase-2 in human-derived colon cancer cells. Int J Cancer 115: 194-201, 2005.

7. Atten MJ, Attar BM, Milson T and Holian O: Resveratrol-induced inactivation of human gastric adenocarcinoma cells through a protein kinase C-mediated mechanism. Biochem Pharmacol 62: 1423-1432, 2001.

8. Jang M, Cai L, Udeani GO, Slowing KV, Thomas CF, Beecher CW, Fong HH, Farnsworth NR, Kinghorn AD, Mehta RG, et al: Cancer chemopreventive activity of resveratrol, a natural product derived from grapes. Science 275: 218-220, 1997.

9. Mahyar-Roemer M, Köhler H and Roemer K: Role of Bax in resveratrol-induced apoptosis of colorectal carcinoma cells. BMC Cancer 2: 27, 2002.

10. Sale S, Verschoyle RD, Boocock D, Jones DJ, Wilsher N, Ruparelia KC, Potter GA, Farmer PB, Steward WP and Gescher AJ: Pharmacokinetics in mice and growth-inhibitory properties of the putative cancer chemopreventive agent resveratrol and the synthetic analogue trans 3,4,5,4'-tetramethoxystilbene. Br J Cancer 90: 736-744, 2004.

11. Ma Z, Molavi O, Haddadi A, Lai R, Gossage RA and Lavasanifar A: Resveratrol analog trans 3,4,5,4'-tetramethoxystilbene (DMU-212) mediates anti-tumor effects via mechanism different from that of resveratrol. Cancer Chemother Pharmacol 63: 27-35, 2008.

12. Androutsopoulos VP, Fragiadaki I and Tosca A: Activation of ERK1/2 is required for the antimitotic activity of the resveratrol analogue 3,4,5,4'-tetramethoxystilbene (DMU-212) in human melanoma cells. Exp Dermatol 24: 632-634, 2015.

13. Androutsopoulos V, Arroo RR, Hall JF, Surichan S and Potter GA: Antiproliferative and cytostatic effects of the natural product eupatorin on MDA-MB-468 human breast cancer cells due to CYP1-mediated metabolism. Breast Cancer Res 10: R39, 2008. 
14. Androutsopoulos VP, Ruparelia KC, Papakyriakou A, Filippakis H, Tsatsakis AM and Spandidos DA: Anticancer effects of the metabolic products of the resveratrol analogue, DMU-212: Structural requirements for potency. Eur J Med Chem 46: 2586-2595, 2011.

15. Piotrowska H, Myszkowski K, Ziółkowska A, Kulcenty K, Wierzchowski M, Kaczmarek M, Murias M, Kwiatkowska-Borowczyk E and Jodynis-Liebert J: Resveratrol analogue 3,4,4',5-tetramethoxystilbene inhibits growth, arrests cell cycle and induces apoptosis in ovarian SKOV-3 and A-2780 cancer cells. Toxicol Appl Pharmacol 263: 53-60, 2012.

16. Mazué F, Colin D, Gobbo J, Wegner M, Rescifina A, Spatafora C, Fasseur D, Delmas D, Meunier P, Tringali C, et al: Structural determinants of resveratrol for cell proliferation inhibition potency: Experimental and docking studies of new analogs. Eur J Med Chem 45: 2972-2980, 2010.

17. Schneider Y, Chabert P, Stutzmann J, Coelho D, Fougerousse A Gossé F, Launay JF, Brouillard R and Raul F: Resveratrol analog (Z)-3,5,4'-trimethoxystilbene is a potent anti-mitotic drug inhibiting tubulin polymerization. Int J Cancer 107: 189-196, 2003.

18. Shen CH, Shee JJ, Wu JY, Lin YW, Wu JD and Liu YW: Combretastatin A-4 inhibits cell growth and metastasis in bladder cancer cells and retards tumour growth in a murine orthotopic bladder tumour model. Br J Pharmacol 160 2008-2027, 2010.

19. Grossman D and Altieri DC: Drug resistance in melanoma: Mechanisms, apoptosis, and new potential therapeutic targets. Cancer Metastasis Rev 20: 3-11, 2001

20. Mooney EE, Ruis Peris JM, O'Neill A and Sweeney EC: Apoptotic and mitotic indices in malignant melanoma and basal cell carcinoma. J Clin Pathol 48: 242-244, 1995.

21. Alotaibi MR, Asnake B, Di X, Beckman MJ, Durrant D, Simoni D, Baruchello R, Lee RM, Schwartz EL and Gewirtz DA: Stilbene $5 \mathrm{c}$, a microtubule poison with vascular disrupting properties that induces multiple modes of growth arrest and cell death. Biochem Pharmacol 86: 1688-1698, 2013.

22. Teng M, Jiang XP, Zhang Q, Zhang JP, Zhang DX, Liang GP and Huang YS: Microtubular stability affects pVHL-mediated regulation of HIF-1alpha via the p38/MAPK pathway in hypoxic cardiomyocytes. PLoS One 7: e35017, 2012.

23. Yang Y,Zhu X, Chen Y, Wang X and Chen R: p38 and JNK MAPK, but not ERK1/2 MAPK, play important role in colchicine-induced cortical neurons apoptosis. Eur J Pharmacol 576: 26-33, 2007.
24. Quan H, Xu Y and Lou L: p38 MAPK, but not ERK1/2, is critically involved in the cytotoxicity of the novel vascular disrupting agent combretastatin A4. Int J Cancer 122: 1730-1737, 2008.

25. Rohena CC, Peng J, Johnson TA, Crews P and Mooberry SL: Chemically diverse microtubule stabilizing agents initiate distinct mitotic defects and dysregulated expression of key mitotic kinases. Biochem Pharmacol 85: 1104-1114, 2013.

26. Aires DJ, Wick J, Shaath TS, Rajpara AN, Patel V, Badawi AH, Li C, Fraga GR, Doolittle G and Liu DY: Economic costs avoided by diagnosing melanoma six months earlier justify $>100$ benign biopsies. J Drugs Dermatol 15: 527-532, 2016.

27. Roman BI, De Coen LM, Thérèse F C Mortier S, De Ryck T, Vanhoecke BW, Katritzky AR, Bracke ME and Stevens CV: Design, synthesis and structure-activity relationships of some novel, highly potent anti-invasive (E)- and (Z)-stilbenes. Bioorg Med Chem 21: 5054-5063, 2013.

28. Zweifel M, Jayson GC, Reed NS, Osborne R, Hassan B, Ledermann J, Shreeves G, Poupard L, Lu SP, Balkissoon J, et al: Phase II trial of combretastatin A4 phosphate, carboplatin and paclitaxel in patients with platinum-resistant ovarian cancer. Ann Oncol 22, 2036-2041, 2011.

29. Maccario C, Savio M, Ferraro D, Bianchi L, Pizzala R, Pretali L, Forti L and Stivala LA: The resveratrol analog 4,4'-dihydroxy-trans-stilbene suppresses transformation in normal mouse fibroblasts and inhibits proliferation and invasion of human breast cancer cells. Carcinogenesis 33: 2172-2180, 2012.

30. Weng CJ, Wu CF, Huang $\mathrm{HW}$, Wu CH, Ho CT and Yen GC: Evaluation of anti-invasion effect of resveratrol and related methoxy analogues on human hepatocarcinoma cells. J Agric Food Chem 58: 2886-2894, 2010.

31. Chen LK, Qiang PF, Xu QP, Zhao YH, Dai F and Zhang L: Trans-3,4,5,4'-tetramethoxystilbene, a resveratrol analog, potently inhibits angiogenesis in vitro and in vivo. Acta Pharmacol Sin 34: 1174-1182, 2013

32. Russo A, Ficili B, Candido S, Pezzino FM, Guarneri C, Biondi A, Travali S, McCubrey JA, Spandidos DA and Libra M: Emerging targeted therapies for melanoma treatment (Review). Int J Oncol 45: 516-524, 2014. 